\title{
Respon Pertumbuhan dan Hasil Tanaman Kubis (Brassica oleracea L.) terhadap Berbagai Dosis Pupuk Kandang Kotoran Itik dengan Penambahan Abu Sekam pada Tanah Rawa Lebak
}

\section{(Growth and Yield Response of Cabbage (Brassica oleracea L.) to Various Dosage Duck Manure With Husk Ash Addition at Lebak Wetland Soil)}

\author{
Mahdalina $^{1}$, Zarmiyeni ${ }^{2}$ \& Nur Hafizah ${ }^{3}$ ) \\ Program Studi Agroteknologi, Sekolah Tinggi Ilmu Pertanian Amuntai \\ ${ }^{1)}$ Mahdawijaya95@gmail.com \\ 2)Zarmiyenilg@yahoo.co.id \\ 3)fifi_bjm@yahoo.co.id
}

\begin{abstract}
ABSTRAK
Mutu dan hasil kubis dapat ditingkatkan melalui pemupukan, salah satunya pupuk kandang kotoran itik sebagai pupuk alternatif dan penambahan abu sekam untuk mendapatkan hasil yang optimal dilahan rawa lebak. Penelitian ini bertujuan menentukan dosis pupuk kandang kotoran itik terhadap pertumbuhan dan hasil tanaman kubis. Penelitian ini dilaksanakan pada bulan Mei - Agustus 2018, bertempat di Desa Teluk Sarikat Kecamatan Banjang Kabupaten Hulu Sungai Utara. Penelitian dilakukan dengan menggunakan Rancangan Acak Kelompok (RAK) dengan faktor tunggal yang terdiri dari 5 taraf dengan 5 perlakuan. Faktor yang diuji adalah dosis pupuk kandang kotoran itik. Data pengamatan dianalisis dengan sidik ragam dan uji lanjut DMRT pada taraf nyata 5\%. Hasil penelitian menunjukan pemberian pupuk kandang kotoran itik dengan berbagai dosis berpengaruh terhadap tinggi tanaman dan jumlah daun tetapi tidak berpengaruh terhadap berat krop tanaman kubis dan keliling krop tanaman kubis. Dosis terbaik pupuk kandang kotoran itik untuk pertumbuhan tanaman kubis adalah 10 ton.ha ${ }^{-1}$ setara dengan $40 \mathrm{~g} /$ polybag $\left(k_{1}\right)$.
\end{abstract}

Kata kunci: Kubis, dosis, pupuk kandang, kotoran itik, abu sekam.

\section{ABSTRACT}

The quality and yield of cabbage can be improved through fertilization, one of which is duck manure as an alternative fertilizer and the addition of husk ash to get optimal results in the lebak wetland. This study aims to determine the doses of dung manure on the growth and yield of cabbage plants. This research was conducted in May-August 2018, located in Teluk Sarikat Village, Banjang District, Hulu Sungai Utara Regency. The study was conducted using a Randomized Block Design $(R B D)$ with a single factor consisting of 5 levels with five treatments. The factors tested were dung manure doses. Observation data were analyzed by variance and DMRT follow-up at 5\% level. The results showed that dosing manure with various doses had an affect plant height and several number of leaves but did not affect the weight of the cabbage crop and around the cabbage crop. The best dose of duck manure for the growth of cabbage plants is 10 tons. Ha-1 equivalent to $40 \mathrm{~g} /$ polybag $\left(k_{1}\right)$.

Keywords: Cabbage, dosage, manure, duck manure, husk ash.

\section{PENDAHULUAN}

Kubis adalah sayuran yang dimanfaatkan daunnya dan bernilai gizi tinggi. Kubis di masyarakat lebih dikenal dengan sebutan kol. Kubis sering dikonsumsi sebagai lalapan, asinan, gadogado, sop dan cap cay. Kubis segar mengandung air, protein, lemak, karbohidrat, serat, glukonisolte, mineral (kalium, kalsium, magnesium, mangan, fosfor, besi, natrium), vitamin $\left(\mathrm{C}, \mathrm{A}, \mathrm{B}_{6}\right.$, biotin, $\mathrm{E}$, tiamin, riboflavin, nicotinamide, folat) dan beta karoten. Tingginya kandungan vitamin $\mathrm{C}$ dalam kubis dapat mencegah timbulnya sariawan akut. Setiap $100 \mathrm{~g}$ kubis yang sudah direbus atau dikukus menyediakan 35 kalori, 2,3 g protein, 0,4 g lemak, 7,2 g karbohidrat dan 3,3 g serat (Patty, 2012). 
Produktivitas tanaman kubis di Kalimantan Selatan pada tahun 2013, yaitu produksi 25 ton dengan luas lahan 7 ha, pada tahun 2014 mengalami penurunan produksi menjadi 4 ton dengan luas lahan 2 ha, dan pada tahun 2015 produksi turun menjadi 7 ton dengan luas lahan 6 ha (BPS Kalimantan Selatan, 2016).

Mengingat semakin meningkatnya permintaan dan kebutuhan kubis dikalangan masyarakat, maka perlu usaha untuk sistem budidaya yang efektif dengan memanfaatkan sumber daya lingkungan sektor pertanian yang dapat meningkatkan hasil dan berkelanjutan, usaha ke arah tersebut dicapai dengan menggunakan pupuk organik yang banyak tersedia di lokasi, seperti pupuk kandang kotoran itik untuk di lahan rawa lebak (Mustina, 2012).

Lahan rawa lebak merupakan lahan yang rendah unsur hara NPK organik tanah. Teksur tanah rawa lebak umumnya dicirikan oleh fraksi liat dan debu yang tinggi, tetapi fraksinya sangat rendah dan terjadi pada lahan rawa lebak adalah mineral yang umumnya masih masam, adanya zat beracun, serta gangguan hama, penyakit dan gulma, sedangkan pemanfaatan bahan organik untuk memperbaiki lahan pertanian kurang diperhatikan, sehingga hal tersebut mengganggu aktivitas mikroorganisme yang sangat berperan penting bagi tanah, karena dapat menyimpan nutrisi yang dibutuhkan tanaman (Noor, 2007).

Kotoran itik merupakan bahan organik yang digunakan sebagai pupuk organik dalam pertanian. Kotoran itik mempunyai kelebihan mempertahankan kesuburan tanah dan melengkapi ketersediaan unsur hara bagi pertumbuhan tanaman. Kotoran itik tergolong pupuk organik dengan kandungan unsur hara yang terdapat dalam kotoran itik bahan kering (Usman et. al., 2012).

Kotoran itik dapat menambah unsur hara yang dapat diserap oleh akar tanaman. Pupuk kandang kotoran itik berpengaruh baik terhadap sifat fisik, kimia, dan biologi tanah. Kelebihan dari pupuk kandang kotoran itik adalah membantu menetralkan pH tanah, aman digunakan dalam jumlah besar, bahkan dalam pertanian organik sumber utama hara berasal dari pupuk kandang, dan mempertinggi porositas tanah dan secara langsung meningkatkan ketersediaan air tanah (Redhanie dalam Mahdiannoor, 2011).

Hasil penelitian Mahdiannoor (2011) menunjukkan bahwa pemberian arang sekam padi dan dosis pupuk kandang kotoran itik yang berpengaruh terhadap semua peubah pengamatan, sedangkan faktor tunggal yang berpengaruh pada peubah tinggi tanaman cabe besar umur 14, 21 dan 28 HST; diameter batang umur 28 35 hst; serta pada peubah pengamatan jumlah buah pertanaman dengan dosis terbaik adalah $\mathrm{s}_{1}\left(20\right.$ t.ha $\left.^{1-}\right)$.

Abu sekam memiliki fungsi mengikat logam berat, selain itu abu sekam berfungsi untuk menggemburkan tanah sehingga bisa mempermudah akar tanaman menyerap unsur hara didalamnya, abu sekam dianggap memiliki daya serap air sedikit, tetapi aerasi udaranya sangat baik. Abu sekam padi sangat kaya akan Si yang dalam oksidasinya untuk memperbaiki tanah, menaikkan $\mathrm{pH}$ pada lahan rawa (Febrynugroho, 2008).

Penelitian ini bertujuan untuk mengetahui respon pertumbuhan dan hasil tanaman kubis terhadap pemberian berbagai dosis pupuk kandang kotoran itik dengan penambahan abu sekam pada tanah rawa lebak dan mendapatkan dosis terbaik pupuk kandang kotoran itik terhadap pertumbuhan dan hasil tanaman kubis dengan penambahan abu sekam pada tanah rawa lebak.

\section{METODE PENELITIAN}

Penelitian ini dilaksanakan di Desa Teluk Sarikat Kecamatan Banjang Kabupaten Hulu Sungai Utara Provinsi Kalimantan Selatan dari bulan Mei sampai bulan Agustus 2018. Bahan yang digunakan dalam penelitian ini adalah benih yang digunakan adalah benih Varietas Sehati $F_{1}$, Polybag, lahan rawa lebak, pupuk kandang kotoran itik, abu sekam padi, air, pestisida nabati, cangkul, parang, gunting, alat tulis, timbangan, gembor, ember, hand sprayer, 
pita ukur dan kamera. Penelitian ini merupakan percobaan yang dilaksanakan di lapangan, dengan menggunakan Rancangan Acak Kelompok (RAK) faktor tunggal, pengelompokkan berdasarkan tinggi tanaman. Faktor yang diteliti adalah dosis pupuk kandang kotoran itik (K) sebanyak 5 taraf, terdiri dari: $\mathrm{k}_{1}=10$ ton.ha ${ }^{-1}$ setara dengan $40 \mathrm{~g} /$ polybag, $\mathrm{k}_{2}=15$ ton.ha $\mathrm{h}^{-1}$ setara dengan $60 \mathrm{~g} /$ polybag, $\mathrm{k}_{3}=20$ ton.ha ${ }^{-1}$ setara dengan $80 \mathrm{~g} /$ polybag, $\mathrm{k}_{4}=25$ ton. $\mathrm{ha}^{-1}$ setara dengan $100 \mathrm{~g} /$ polybag dan $\mathrm{k}_{5}=30$ ton.ha ${ }^{-1}$ setara dengan $120 \mathrm{~g} /$ polybag. Perlakuan dosis pupuk kandang kotoran itik ini dikelompokkan sebanyak 5 kelompok sehingga didapat 25 satuan percobaan, setiap satuan percobaan terdiri 4 sampel tanaman. Pengamatan yang dilakukan adalah tinggi tanaman, jumlah daun umur 14, 21, 28 dan 35 HST, berat krop dan keliling krop tanaman kubis. Analisis statistik yang dilakukan adalah uji kehomogenan ( $\alpha: 5 \%)$ uji $F(\alpha: 5 \%$ dan $1 \%)$ dan uji beda rata-rata DMRT $(\alpha: 5 \%)$.

\section{HASIL DAN PEMBAHASAN}

\section{Hasil}

\section{Tinggi Tanaman}

Data hasil pengamatan dan analisis ragam jumlah daun tanaman kubis umur 14, 21, 28 dan 35 HST. Hasil analisis ragam menunjukkan bahwa perlakuan pemberian dosis pupuk kandang kotoran itik memberikan respon nyata terhadap tinggi tanaman pada umur 14 HST, tetapi pada umur 21, 28, dan 35 HST berespon sangat nyata. Hasil uji beda rata-rata dapat dilihat pada Tabel 1.

Tabel 1. Hasil uji beda rata-rata tinggi tanaman kubis terhadap pemberian dosis pupuk kandang kotoran itik pada tanah rawa lebak.

\begin{tabular}{ccccc}
\hline \multirow{2}{*}{ Perlakuan } & \multicolumn{4}{c}{ Rata-rata tinggi tanaman $(\mathrm{cm})$} \\
\cline { 2 - 5 } & $14 \mathrm{HST}$ & $21 \mathrm{HST}$ & $28 \mathrm{HST}$ & $35 \mathrm{HST}$ \\
\hline $\mathrm{k}_{1}$ & $11,8^{\mathrm{c}}$ & $16,95^{\mathrm{b}}$ & $21,85^{\mathrm{c}}$ & $28^{\mathrm{b}}$ \\
$\mathrm{k}_{2}$ & $12,15^{\mathrm{d}}$ & $16,2^{\mathrm{b}}$ & $22^{\mathrm{d}}$ & $28,35^{\mathrm{b}}$ \\
$\mathrm{k}_{3}$ & $9,05^{\mathrm{b}}$ & $12,5^{\mathrm{a}}$ & $16,65^{\mathrm{b}}$ & $21,85^{\mathrm{a}}$ \\
$\mathrm{k}_{4}$ & $8,1^{\mathrm{a}}$ & $11,05^{\mathrm{a}}$ & $14,7^{\mathrm{a}}$ & $19,5^{\mathrm{a}}$ \\
$\mathrm{k}_{5}$ & $8,95^{\mathrm{a}}$ & $11,1^{\mathrm{a}}$ & $16,05^{\mathrm{b}}$ & $22,5^{\mathrm{a}}$ \\
\hline
\end{tabular}

Keterangan: Nilai rata-rata yang diikuti oleh huruf yang sama pada kolom yang sama menunjukkan perlakuan tersebut berbeda berdasarkan uji DMRT pada taraf nyata $5 \%$.

Dari Tabel 1 pada umur 14 HST menunjukkan bahwa perlakuan $\mathrm{k}_{2}$ berbeda dengan perlakuan $\mathrm{k}_{1}, \mathrm{k}_{3}, \mathrm{k}_{4}$ dan $\mathrm{k}_{5}$. Pada umur 21 HST menunjukkan bahwa perlakuan $\mathrm{k}_{1}$ tidak berbeda dengan perlakuan $\mathrm{k}_{2}$ tetapi berbeda dengan perlakuan $\mathrm{k}_{3}$, $\mathrm{k}_{4}$ dan $\mathrm{k}_{5}$. Pada umur $28 \mathrm{HST}$ menunjukkan bahwa perlakuan $\mathrm{k}_{2}$ berbeda dengan perlakuan $\mathrm{k}_{1}, \mathrm{k}_{3}, \mathrm{k}_{4}$ dan $\mathrm{k}_{5}$. Pada umur 35 HST menunjukkan bahwa perlakuan $\mathrm{k}_{1}$ tidak berbeda dengan perlakuan $\mathrm{k}_{2}$ tetapi berbeda dengan perlakuan $\mathrm{k}_{3}, \mathrm{k}_{4}$ dan $\mathrm{k}_{5}$. Perlakuan terbaik pada tinggi tanaman kubis didapat pada dosis 10 ton.ha ${ }^{-1}$ setara dengan 40 $\mathrm{g} /$ polybag $\left(\mathrm{k}_{1}\right)$.

\section{Jumlah Daun}

Data hasil pengamatan dan analisis ragam jumlah daun tanaman kubis umur 14, 21, 28 dan 35 HST. Hasil analisis menunjukkan bahwa perlakuan pemberian dosis pupuk kandang kotoran itik memberikan respon nyata terhadap jumlah daun pada umur 21 dan 35 HST tetapi umur 14 dan 28 HST berespon sangat nyata. Hasil beda uji rata-rata dapat dilihat pada Tabel 2. 
Tabel 2. Hasil uji beda rata-rata jumlah daun tanaman kubis terhadap pemberian dosis pupuk kandang kotoran itik pada tanah rawa lebak

\begin{tabular}{ccccc}
\hline \multirow{2}{*}{ Perlakuan } & \multicolumn{4}{c}{ Rata-rata jumlah daun (helai) } \\
\cline { 2 - 5 } & $14 \mathrm{HST}$ & $21 \mathrm{HST}$ & $28 \mathrm{HST}$ & $35 \mathrm{HST}$ \\
\hline $\mathrm{k}_{1}$ & $6,4^{\mathrm{b}}$ & $7,75^{\mathrm{b}}$ & $10^{\mathrm{b}}$ & $11,45^{\mathrm{b}}$ \\
$\mathrm{k}_{2}$ & $6,25^{\mathrm{b}}$ & $7,75^{\mathrm{b}}$ & $9,4^{\mathrm{b}}$ & $11,65^{\mathrm{b}}$ \\
$\mathrm{k}_{3}$ & $5,1^{\mathrm{a}}$ & $6,75^{\mathrm{ab}}$ & $7,6^{\mathrm{a}}$ & $9,1^{\mathrm{ab}}$ \\
$\mathrm{k}_{4}$ & $4,8^{\mathrm{a}}$ & $5,85^{\mathrm{a}}$ & $6,65^{\mathrm{a}}$ & $8,45^{\mathrm{a}}$ \\
$\mathrm{k}_{5}$ & $4,8^{\mathrm{a}}$ & $5,8^{\mathrm{a}}$ & $6,75^{\mathrm{a}}$ & $9,2^{\mathrm{a}}$ \\
\hline
\end{tabular}

Keterangan: Nilai rata-rata yang diikuti oleh huruf yang sama pada kolom yang sama menunjukkan perlakuan tersebut berbeda berdasarkan uji DMRT pada taraf nyata $5 \%$.

Dari Tabel 2 pada umur 14, 21, 28 dan 35 HST menunjukkan bahwa perlakuan $\mathrm{k}_{1}$ tidak berbeda dengan perlakuan $\mathrm{k}_{2}$, tetapi berbeda dengan perlakuan $\mathrm{k}_{3}$, $\mathrm{k}_{4}$ dan $\mathrm{k}_{5}$. Perlakuan terbaik pada jumlah daun tanaman kubis didapat pada dosis 10 ton.ha ${ }^{-}$ ${ }^{1}$ setara dengan $40 \mathrm{~g} /$ polybag $\left(\mathrm{k}_{1}\right)$.
Hasil analisis ragam menunjukkan bahwa pemberian pupuk kandang kotoran itik tidak memberikan respon terhadap berat krop tanaman kubis. Grafik rata-rata berat krop tanaman kubis terhadap pemberian pupuk kandang kotoran itik dapat dilihat pada Gambar 1.

\section{Berat Krop tanaman kubis}

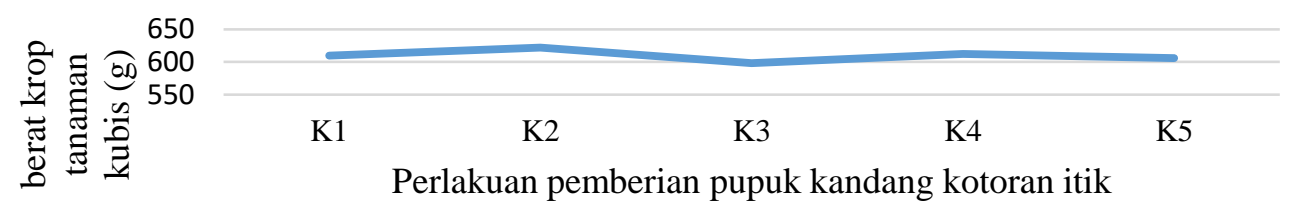

Gambar 1. Grafik rata-rata berat krop tanaman kubis terhadap pemberian dosis pupuk kandang kotoran itik.

Berdasarkan grafik di atas pada pengamatan berat krop tanaman kubis bahwa perlakuan $\mathrm{k}_{2}$ menunjukkan rata-rata berat terbesar yaitu $622,1 \mathrm{~g}$.

Keliling krop tanaman kubis
Hasil analisis ragam menunjukkan bahwa pemberian dosis pupuk kandang kotoran itik tidak memberikan respon terhadap keliling krop tanaman kubis. Grafik rata-rata keliling krop tanaman kubis terhadap pemberian dosis pupuk kandang kotoran itik dapat dilihat pada Gambar 2.

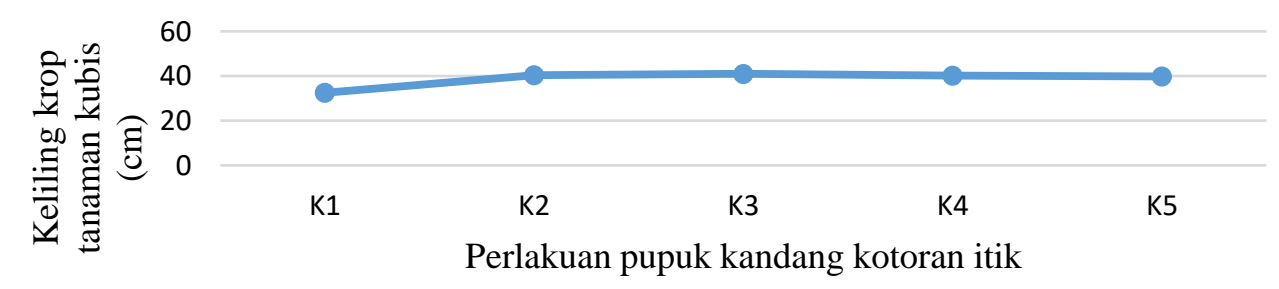

Gambar 2. Grafik rata-rata keliling krop kubis terhadap pemberian pupuk kandang kotoran itik 
Berdasarkan grafik di atas pada pengamatan keliling krop tanaman kubis bahwa perlakuan $\mathrm{k}_{3}$ menunjukkan rata-rata keliling krop terbesar yaitu $41 \mathrm{~cm}$.

\section{Pembahasan}

Berdasarkan analisis ragam terlihat bahwa tinggi tanaman umur 14 HST memberikan respon nyata, tetapi berespon sangat nyata pada umur 21, 28, dan 35 HST. Pada jumlah daun umur 14 dan 28 HST berespon sangat nyata, tetapi pada umur 21 dan 35 HST memberikan respon nyata dengan pemberian dosis pupuk kandang kotoran itik dengan penambahan abu sekam pada lahan rawa lebak. Hal ini disebabkan pada tinggi tanaman dan jumlah daun tanaman kubis pada pertumbuhan vegetatif pupuk kandang kotoran itik merupakan pupuk organik yang berperan dalam perbaikan sifat fisik, kimia, dan biologi tanah. Menurut Kapugu dalam Rina (2012), peranan pupuk organik terhadap sifat fisik tanah adalah memperbaiki struktur tanah. Pada perbaikan sifat kimia tanah pupuk organik menyumbang hara ke tanah dan meningkatkan kapasitas tukar kation (KTK) tanah. Sedangkan perbaikan sifat biologi tanah, pupuk organik yang berasal dari berbagai sumber bahan organik dapat membawa jasad renik yang bermanfaat bagi perbaikan sifat fisik dan kimia tanah, pada akhirnya akan berpengaruh pada pertumbuhan tanaman.

Selain unsur hara yang di kandung pupuk kandang kotoran itik, kandungan bahan organik tanah dapat meningkatkan agregasi dan porositas tanah sehingga meningkatkan aerase tanah. Peningkatan aerase tanah menunjang pertumbuhan akar yang berperan dalam proses penyerapan nutrisi, meningkatkan pertumbuhan akar, memungkinkan penetrasi akar kedalam tanah menjadi mudah dan luas (Nurhayati dan Raharjdo, 2008).

Unsur hara nitrogen diperlukan untuk pertumbuhan batang dan daun berperan dalam pertumbuhan vegetatif tanaman (Akbar, 2010). Menurut Maspari (2010), kalium membantu pembentukan protein dan karbohidrat. Berperan memperkuat tubuh tanaman agar daun tidak mudah gugur. Meningkatkan daya tahan tanaman terhadap kekeringan. Fosfor merangsang pertumbuhan akar, khususnya tanaman muda.

Penambahan abu sekam pada tanah rawa lebak telah mengubah sifat fisik dan kimia tanah. Sifat tanah yang mulanya liat menjadi gembur, dimana hal ini dapat meningkatkan kemampuan untuk memperbaiki aerasi dan drainase tanah, sehingga akar dapat lebih dalam luas menembus dan menyerap tanah hara tanaman. Pemberian abu sekam dapat meningkatkan ketersediaan unsur hara $\mathrm{K}$, kerena dengan pemberian abu sekam akan meningkatkan $\mathrm{pH}$ tanah (Radjagukguk \& Jutono, 1983 dalam Nupiana 2011).

$$
\text { Menurut Hanafiah (2005), }
$$

menyatakan bahwa pada $\mathrm{pH}$ rendah ketersediaan $\mathrm{K}$ juga rendah dan sebaliknya. Menurut Astri (2011), fungsi K bagi tanaman adalah membantu pembentukan protein dan karbohidrat, $\mathrm{K}$ berperan memperkuat tubuh tanaman, meningkatkan daya tahan tanaman terhadap kekeringan serta dapat meningkatkan mutu dari biji/buah.

Berdasarkan hasil analisis tanah Balittra (2018) menunjukan bahwa kandungan $\mathrm{N}$-total dengan kriteria sedang yaitu $0,21 \%$, C-organik dengan kriteria rendah $1,36 \%$, Kdd dengan kriteria rendah $0,14(\mathrm{cmol}+/ \mathrm{kg}), \mathrm{P}$ bray 1 dengan kriteria sangat rendah 6,30 Ppm, Cadd dengan kriteria rendah 4,70(cmol+/kg), Mg dengan kriteria tinggi 5,66 (cmol+/kg), $\mathrm{PH} \mathrm{H}_{2} \mathrm{O}$ dengan kriteria agak alkalis 7,97 dan $\mathrm{C} / \mathrm{N}$ dengan kriteria rendah $6,41 \%$ dan analisis pupuk kandang kotoran itik $\mathrm{C}$ organik kandungannya 8,72 dengan kriteria sangat tinggi, $\mathrm{N}$ total kandungannya 0,41 kriteria sedang, $\mathrm{P}$ kandungannya 2,66 dengan kriteria sangat rendah, $\mathrm{K}$ kandungannya 0,03 dengan kriteria sangat rendah, $\mathrm{pH} \mathrm{H}_{2} \mathrm{O}$ kandungannya 7,65 dengan kriteria agak alkalis, $\mathrm{Mg}$ kandungannya 0,75 dengan kriteria rendah dan $\mathrm{Ca}$ dengan kadungan 19,38 dengan kriteria tinggi.

Berdasarkan hasil analisis data, perlakuan dosis pupuk kandang kotoran itik yang diberikan ternyata berpengaruh nyata 
terhadap pertumbuhan vegetatif tinggi tanaman dan jumlah daun tanaman kubis, dimana perlakuan terbaik didapat pada dosis 15 ton.ha ${ }^{-1}$ atau setara dengan 60 g/polybag. Menurut Baherta (2009), secara fisik penambahan pupuk kandang mampu menciptakan kondisi tanah yang lebih baik bagi pertumbuhan bibit, karena pupuk kandang dapat meningkatkan bahan organik tanah dan ketersediaan unsur hara, sehingga mendukung kecepatan tumbuh.

Berdasarkan analisis ragam pada pengamatan berat krop tanaman kubis dan keliling krop tanaman kubis tidak memberikan respon karena pada pertumbuhan tanaman dipengaruhi oleh ketersediaan unsur hara yang dibutuhkan dalam jumlah yang cukup, yang dapat diperoleh dari penambahan unsur hara dari luar. Karena pada kedua fase pertumbuhan vegetatif ke generatif pada pemberian dosis pupuk kandang kotoran itik memberikan respon, artinya kandungan hara yang ada pada tanah dan pupuk kandang kotoran itik mampu mencukupi kebutuhan hara tanaman. Hal ini sejalan dengan pernyataan Marliah et. al., (2012), menyatakan kebutuhan hara makro dan mikro dalam jumlah optimal akan mendorong pertumbuhan dan hasil tanaman menjadi lebih baik. Pengaruh lingkungan juga dapat mempengaruhi pertumbuhan dan hasil kubis serangan hama dan penyakit. Faktor serangan hama seperti ulat perusak daun (Plutella xylostella) dan ulat grayak (Spodoptera litura) merupakan salah satu kendala dalam pertumbuhan dan hasil kubis. Selama pertumbuhan generatif ulat perusak daun banyak menyerang tanaman kubis. Ulat yang berwarna hijau ini memakan permukaan daun bagian bawah dengan meninggalkan tulang-tulang daun sehingga daun berlubang. Kondisi ini akan mengganggu proses fotosintesis kubis karena penangkapan energi cahaya untuk fotosintesis tidak efesien, akibatnya fotosintat yang dihasilkan juga akan berkurang. Pada saat pembentuk krop tanaman kubis semakin lama unsur hara yang ada didalam tanah tersebut akan berkurang karena terbatas unsur hara tersebut sehingga menyebabkan tidak berpengaruh tehadap berat krop dan keliling krop tanaman kubis.

Menurut Hikmah (2015) menyatakan bahwa berat segar suatu tanaman dipengaruhi oleh kadar air dan kandungan fotosintat yang ada dalam selsel dan jaringan tanaman, sehingga apabila fotosintat yang terbentuk meningkat maka berat segar tanaman juga akan meningkat. Berat segar merupakan akumulasi fotosintat yang dihasilkan selama pertumbuhan. Hal ini mencerminkan tingginya serapan nutrisi yang diserap tanaman untuk proses pertumbuhan.

Menurut Arianti (2010) air salah satu faktor penting dalam produksi tanaman. Keberhasilan yang terjadi dalam sistem penanaman akan tercapai apabila diatur waktu dan jumlah pemberian airnya. Air harus tersedia dalam tanah untuk mengantikan air yang hilang karena evaporasi dari tanah dan transpirasi dari tanah. Air didalam tanh selalu membawa nutrisi dalam larutannya untuk pertumbuhan tanaman dan berpengaruh pada aerasi dan suhu tanah. Air sangat dibutuhkan oleh tanaman karena merupakan komponen utama dalam sel-sel untuk menyusun jaringan tanaman. Peran air sebagai pelarut unsur hara didalam tanah menyebabkan tanaman dapat dengan mudah mengambil hara tersebut bahan makanan melalui akar dan sekaligus mengakut hara tersebut ke bagian-bagian tanaman yang memerlukan melalui pembuluh xilem.

\section{KESIMPULAN}

Berdasarkan hasil penelitian dapat disimpulkan pemberian berbagai dosis pupuk kandang kotoran itik memberikan respon terhadap tinggi tanaman dan jumlah daun pada umur 14, 21, 28 dan 35 HST, tetapi tidak memberikan respon terhadap berat krop dan keliling krop tanaman kubis. Dosis terbaik untuk pemberian pupuk kandang kotoran itik terhadap tinggi tanaman dan jumlah daun tanaman kubis adalah 10 ton.ha $^{-1}$ setara dengan 40 $\mathrm{g} /$ polybag $\left(\mathrm{k}_{1}\right)$. 
Mahdalina, Zarmiyeni \& Nur Hafizah, Respon pertumbuhan dan hasil tanaman...

\section{DAFTAR PUSTAKA}

Akbar, J. (2010, February 23). Ilmu Tanah. Retrieved from Joni akbar's Blog: https://bibirmemble.wordpres s.com/.

Arianti, A. (2010, Oktober 20). AgronomyAgriculture. Retrieved from exact sciences: http://id.shvoong.com/.

Ballitra. (2018). Hasil Analisisis Tanah Rawa Lebak. Banjarbaru: Balai Penelitian Pertanian Lahan Rawa (Balittra).

BPS Kalimantan Selatan. (2016). Produksi Tanaman Sayuran dan BuahBuahan Provinsi Kalimantan Selatan. Banjarbaru: Badan Pusat Statistik Provinsi Kalimantan Selatan.

Baherta. (2009). Respon Bibit Kopi Arabika pada Beberapa Takaran Pupuk Kandang Kotoran Ayam. J. Ilmiah Tambua 8(3), 467-472.

Nugroho, F. S. (2009, March 3). Manfaat Abu Sekam Padi. Retrieved from Febrysetyonugroho's Weblog: https://febrynugroho.wordpress.co $\mathrm{m} /$

Hanafiah, K. A. (2005). Dasar-dasar Ilmu Tanah. Jakarta: PT Raja Grafindo Persada.

Haruna. (2011, July 26). Unsur Makro dan Mikro pada Tumbuhan. Retrieved from Light In My Path: http://anieensama.wordpress.com.

Hikmah, S. (2015). Pengaruh Pupuk Cair terhadap Pertumbuhan Hasil dan Kualitas Tiga Varietas Bunga Kol (Brassica oleracea var.botrytis.L).
(Skripsi) Jember: Fakultas Pertanian UNEJ.

Mahdiannoor. (2011). Respon Pertumbuhan Dan Hasil Tanaman Cabe Besar (Capsicum annum L.) terhadap Pemberian Arang Sekam Padi dan Dosis Pupuk Kandang Kotoran Itik Di Lahan Rawa Lebak. Jurnal Agroscientiae, 18(3), 164-171.

Marliah. A. Nurhayati dan Risma R. (2013). Pengaruh Varietas dan Konsentrasi Pupuk Majemuk terhadap Pertumbuhan dan Hasil Tanaman Kubis (Brassica oleracea L.). Jurnal Floratek 8, 118-126.

Maspari. A. (2018, September 15). Fungsi unsur hara bagi pertumbuhan. Retrieved from gerbang pertanian: http://www.gerbangpertanian.com

Mustina. (2017, Nopember 25). Pengaruh Pemberian Pupuk Kotoran Sapi dan Kotoran Itik terhadap Pertumbuhan dan Hasil Tanaman Kol Bunga. Retrieved from mustina: http://mustinakampus. blogspot.com/ html. .

Nupiana, W. (2011). Pengaruh Pemberian Abu Sekam Padi terhadap Pertumbuhan dan Hasil Tanaman Kacang Panjang ( Vigna sinensis L.) pada tanah rawa lebak. (Skripsi). Amuntai: Program Studi Agroteknologi, Sekolah Tinggi Ilmu Pertanian Amuntai.

Noor, M. (2007). Lebak Pemanfaatan dan Pengembangannya. Jakarta: Raja Grafindo Persada.

Nurhayati, S. M. D. dan Raharjdo, M. (2008). Pengaruh dosis pupuk kandang terhadap hasil akar dan kadar minyak atsiri valerian (Valeriana offcinalis L.). Bogor: Balai Penelitian Tanaman Obat dan Aromatik. 
Patty, J.A. (2012). Peran Tanaman Aromatik dalam Menekan Perkembangan Hama Spodoptera litura pada Tanaman Kubis. Jurnal Agrologia : Ilmu Budidaya Tanaman. 1(2):126-133. DOI: http://dx.doi. org/10.30598/a.v 1i2. 288.

Rina, H. P. (2012). Pengaruh pemberian pupuk kandang kotoran itik terhadap pembibitan kunyit putih (Curcuma zedoaria Berg) pada tanah rawa lebak. (Skripsi). Amuntai: Program Studi Agroteknologi Sekolah Tinggi Ilmu Pertanian Amuntai.

Usman, M. A., Anwar \& Purbajanti. E. D. (2012). Serapan Nitrogen dan Fosfor Tanaman Eceng Gondok Sebagai Sumber Daya Pakan pada "Perairan" yang Mendapatkan Kotoran Itik. Animal Agricultural Journal 1(1), 789-796. 